\title{
Monitoring of glucose-regulated single insulin secretory granule movement by selective photoactivation
}

\author{
S. Baltrusch • S. Lenzen
}

Received: 14 December 2007 / Accepted: 7 February 2008 /Published online: 4 April 2008

(C) Springer-Verlag 2008

\begin{abstract}
Aims/hypothesis Fluorescence microscopy opens new perspectives for the analysis of insulin secretory granule movement. In this study, we examined whether recently developed photoactivatable/photoconvertible proteins are a useful tool for studying this process at the single granule level in insulin-secreting cells after glucose stimulation.

Methods Plasmids were generated for expression of fusion proteins of the granule membrane phosphatase phogrin or the granule cargo protein neuropeptide Y (NPY) with the photoactivatable green fluorescent protein mutant A206K (PA-GFPA206K), the photoconvertible protein Dendra2 and the fluorescent protein mCherry. Transfected insulin-secreting MIN6 cells were analysed by fluorescence microscopy.

Results Point-resolved $405 \mathrm{~nm}$ light exposure during image acquisition of MIN6 cells transiently transfected with Phogrin-PA-GFP-A206K or NPY-PA-GFP-A206K as well as of stable MIN6-Phogrin-Dendra2 cells resulted in selective visualisation of few granules by green or red fluorescence, respectively. Movement of these granules was analysed by an automated tracking method from confocal 3D image series. The high spatiotemporal resolution facilitated an elongated tracking of single granules. Interestingly, the track speed and track displacement of granules after $1 \mathrm{~h}$ starvation and subsequent glucose stimulation was lower in cells pre-cultured for $48 \mathrm{~h}$ at $3 \mathrm{mmol} / \mathrm{l}$ glucose than in cells pre-cultured at $25 \mathrm{mmol} / \mathrm{l}$ glucose.

Conclusions/interpretation Targeting of the granule membrane or its cargo with a photoactivatable/photoconvertible
\end{abstract}

S. Baltrusch $(\bowtie) \cdot S$. Lenzen

Institute of Clinical Biochemistry,

Hannover Medical School,

30623 Hannover, Germany

e-mail: baltrusch.simone@mh-hannover.de protein allows in-depth visualisation and tracking of single insulin granules in dependence upon glucose. This technique may also open the way to elucidating the regulation of granule movement velocity within the pancreatic beta cell with respect to secretory defects in type 2 diabetes.

Keywords Dendra2 - Fluorescence microscopy Glucose regulated · Insulin granules · Insulin secretion · Pancreatic beta cell $\cdot$ Photoactivation $\cdot$ Photoconversion . Single granule movement . Type 2 diabetes

$\begin{array}{ll}\text { Abbreviations } \\ \text { EGFP } & \text { enhanced green fluorescent protein } \\ \text { EYFP } & \text { enhanced yellow fluorescent protein } \\ \text { NPY } & \text { neuropeptide Y } \\ \text { PA-GFP- } & \text { photoactivatable green fluorescent protein } \\ \text { A206K } & \text { mutant A206K } \\ \text { TIRF } & \text { total internal reflection fluorescence } \\ \text { 3D } & \text { three-dimensional }\end{array}$

\section{Introduction}

Intracellular transport and exocytosis of insulin is a prerequisite for glucose-induced insulin secretion in pancreatic beta cells $[1,2]$. The mechanism underlying beta cellcharacteristic biphasic insulin release requires proper packaging of the insulin-containing dense core vesicles, their translocation, docking and fusion to the plasma membrane [3-11]. In recent years, targeting the membrane as well as the cargo of the insulin granules by fluorescent fusion proteins has provided new insights into these processes $[3,10,12-$ 20]. Transfection of beta cells with EGFP-tagged insulin revealed different kinds of insulin granule movement during 
the first and second phase of release [21]. Insulin granule membrane labelling by Phogrin-EGFP facilitated the characterisation of granule translocation and diffusion, in particular with respect to direction, association with the cytoskeleton and proximity to the plasma membrane $[11,22$, 23]. Quantitative live cell imaging described the regulation of different granule populations [12]. The introduction of total internal reflection fluorescence (TIRF) microscopy, which allows fluorescence excitation within $100 \mathrm{~nm}$ from the plasma membrane, has promoted the analysis of docking and fusion of insulin granules [21]. Thus, exocytosis could be described with respect to the release of soluble cargo molecules and granule membrane proteins [23].

Tracking of single insulin granules within the cytoplasm beyond the readily releasable pool by real-time fluorescence microscopy has so far been less accessible. In the present study, we visualised single insulin granules in insulin-secreting MIN6 cells through selective photoactivation or photoconversion and analysed their movement in response to glucose. The results show that track speed and track displacement of granules after glucose stimulation was lower in cells pre-cultured for $48 \mathrm{~h}$ at $3 \mathrm{mmol} / \mathrm{l}$ glucose than in cells pre-cultured at $25 \mathrm{mmol} / \mathrm{l}$ glucose. These data suggest that glucose has a direct effect on the movement of insulin granules that are not part of the readily releasable granule pool.

\section{Methods}

Materials Restriction enzymes and modifying enzymes for the cloning procedures were from New England Biolabs (Beverly, MA, USA) or Fermentas (St Leo-Rot, Germany). All reagents of analytical grade were from Merck (Darmstadt, Germany). Primers and tissue culture equipment were from Invitrogen (Karlsruhe, Germany).

Construction of fluorescence fusion plasmids For generation of Phogrin-mCherry, Phogrin-photoactivatable green fluorescent protein mutant A206K (PA-GFP-A206K), neuropeptide Y (NPY)-mCherry and NPY-PA-GFP-A206K, the fluorescence proteins in Phogrin-enhanced yellow fluorescent protein (EYFP) and in NPY-Venus were replaced by mCherry [24] and PA-GFP-A206K [25], respectively using AgeI and BsrGI restriction sites. The cDNA of phogrin was subcloned in frame into the EcoRI and AgeI sites of the pDendra2-N vector (Evrogen, Moscow, Russia) [26] to generate Phogrin-Dendra2.

Cell culture and transfection Insulin-producing MIN6 cells (passages 35-45) were grown in DMEM medium supplemented with $25 \mathrm{mmol} / 1$ glucose, $10 \%$ (vol./vol.) fetal calf serum, and penicillin and streptomycin in a humidified atmosphere at $37^{\circ} \mathrm{C}$ and $5 \% \mathrm{CO}_{2}$. For transient transfection cells were seeded at a density of $7 \times 10^{4}$ cells on $35 \mathrm{~mm}$ collagen-coated glass bottom dishes (MatTek, Ashland, MA, USA). After $48 \mathrm{~h}$, co-transfection was performed with $1.5 \mu \mathrm{g}$ plasmid DNA each and $6 \mu \mathrm{l}$ jetPEI (Qbiogene, Montreal, QC, Canada) according to manufacturer's instructions. Thereafter cells were cultured for further $48 \mathrm{~h}$ in DMEM medium supplemented with $25 \mathrm{mmol} / \mathrm{l}$ glucose. During imaging cells were incubated in Krebs-Ringer solution supplemented with $25 \mathrm{mmol} / \mathrm{l}$ glucose. For generation of a stable MIN6 cell clone, cells were seeded at a density of $1.5 \times 10^{5}$ cells on $35 \mathrm{~mm}$ dishes and transfected with the vector pDendra2-NPhogrin by the use of jetPEI. Positive clones were selected through resistance against $\mathrm{G} 418(1,100 \mu \mathrm{g} / \mathrm{ml})$ and characterised for Dendra2 expression by fluorescence microscopy. MIN6-Phogrin-Dendra2 (K4) cells were seeded at a density of $1 \times 10^{5}$ cells on $35 \mathrm{~mm}$ collagen-coated glass bottom dishes (MatTek) and cultured for $48 \mathrm{~h}$ in DMEM medium supplemented with 3 or $25 \mathrm{mmol} / \mathrm{l}$ glucose. Initially cells were starved for $1 \mathrm{~h}$ in Krebs-Ringer solution supplemented without glucose. Thereafter cells were incubated in KrebsRinger solution supplemented with $25 \mathrm{mmol} / \mathrm{l}$ glucose and image acquisition immediately started.

Insulin secretion MIN6 and MIN6-Phogrin-Dendra2 cells were washed in Krebs-Ringer buffer. Thereafter perifusion of $1 \times 10^{6}$ cells was performed in a closed system at $37^{\circ} \mathrm{C}$ with $95 \% \mathrm{O}_{2}$ and $5 \% \mathrm{CO}_{2}$ in bicarbonate-buffered Krebs-Ringer solution supplemented with $0.1 \%$ albumin and without glucose, with $20 \mathrm{mmol} / 1$ glucose or with $40 \mathrm{mmol} / \mathrm{l} \mathrm{KCl}$. Insulin was measured radioimmunologically with rat insulin as a standard [27].

Immunostaining Transiently transfected MIN6 cells or MIN6Phogrin-Dendra2 cells grown on collagen type I glass cover slips in medium with $25 \mathrm{mmol} / \mathrm{l}$ glucose were washed twice with PBS (pH 7.4), fixed with ice-cold acetone for $5 \mathrm{~min}$ and immunostained as previously described [27] with guinea pig polyclonal insulin antibody (ab-7842; Abcam, Cambridge, UK) diluted 1:100 in PBS. Thereafter cells were incubated with Cy5 donkey anti-guinea pig secondary antibody, diluted 1:200 in PBS (Jackson Immuno Research, West Grove, PA, USA). Finally, cover slips were mounted on to slides using ProLong antifade reagent in mounting medium (Molecular Probes Invitrogen Detection Technologies, Eugene, OR, USA).

Fluorescence microscopy Experiments were performed with an Olympus Fluoview1000 confocal inverted microscope (Olympus, Hamburg, Germany) using the multi-line argon laser $(488 \mathrm{~nm})$ to excite PA-GFP and green Dendra2, the krypton-argon laser $(561 \mathrm{~nm})$ to excite mCherry and red Dendra2, and an UPLSAPO $60 \times 1.35$ NA oil-immersion objective. The light emitted by PA-GFP was detected at 500 to 
$540 \mathrm{~nm}$ wavelength range together that emitted by mCherry at 570 to $650 \mathrm{~nm}$. Light emitted by green Dendra2 was detected at 490 to $540 \mathrm{~nm}$ wavelength range together with that emitted by red Dendra2 at 560 to $660 \mathrm{~nm}$. Scanning was performed with $2 \mu \mathrm{s} /$ pixel sampling speed and $256 \times 256$ image format, resulting in a sampling interval of $0.428 \mathrm{~s}$ for a single $\mathrm{z}$-layer and $3.57 \mathrm{~s}$ when acquiring five z-layers with $0.4 \mu \mathrm{m}$ spacing. Photoactivation and photoconversion were done for one sampling interval during imaging with simultaneous scanner and a $405 \mathrm{~nm}$ laser diode (25 $\mathrm{mW}$ ) using circular scanning (tornado mode). Cells were maintained at $37^{\circ} \mathrm{C}$ using a thermostatically controlled chamber. Image processing was performed using Olympus FV10-ASW 1.6 software and AutoVisualize X software (MediaCybernetics, Silver Spring, MD, USA). Granule movement analysis was carried out with ImarisTrack (Imaris 5.5 software; Bitplane, Zurich, Switzerland) selecting a $0.6 \mu \mathrm{m}$ spot diameter for automatic granule detection over time. Thereafter, consecutive time-points were linked using the autoregressive motion algorithm (maximum distance of $1.5 \mu \mathrm{m}$ ). Finally tracks were displayed automatically and parameters such as track length, duration, displacement and speed were calculated. For calculations that are indicated as semi-automatic, manual track adjustment and sorting of tracks with a length $>50 \mathrm{~s}$ were performed. Furthermore a cell ${ }^{\mathrm{R}} /$ Olympus IX81 inverted microscope system (Olympus), as described previously, was used [27, 28]. Glass bottom dishes and slides were fixed on the microscope stage and images were obtained with a PlanApo $100 \times 1.45$ NA oil-immersion objective (Olympus). S 492/18 and S 572/23 excitation filters were used for PA-GFP, mCherry and Dendra2, respectively, and a DAPI/FITC/ TxRed triple band beam splitter and emitter. An S360/40 excitation filter was used for photoactivation and photoconversion. An HQ620/60-Q660LP-HQ700/75 filter set (AHF Analysentechnik, Tübingen, Germany) was used for Cy5. Real-time imaging was performed with a sampling interval of $0.729 \mathrm{~s}$. Image processing was performed using cell $^{\mathrm{R}} 2.6$ software (Olympus). Deconvolution of images from fixed samples was performed using AutoDeblur 9.3 WF software (MediaCybernetics, Silver Spring, MD, USA).

Statistical analyses Data are expressed as means \pm SEM. Statistical analyses were performed by Student's $t$ test using the Prism analysis program (Graphpad, San Diego, CA, USA).

\section{Results}

Spatial analysis of insulin granule movement by photoactivation of Phogrin-PA-GFP-A206K or NPY-PA-GFP-A206K Region-selected $405 \mathrm{~nm}$ laser light exposure using a confocal microscope equipped with a second simultaneous working scanner allowed $\geq 50 \%$ of the experiments in visualisation of three or $\geq 20 \%$ of those in visualisation of a single granule of PA-GFP-A206K-labelled granules by green fluorescence. Thereafter granule movement could be tracked over several minutes. To display all granules, MIN6 cells were either transfected with NPY-mCherry in addition to Phogrin-PA-GFP-A206K or Phogrin-mCherry in addition to NPY-PA-GFP-A206K. MIN6 cells co-transfected with Phogrin-PA-GFP-A206K and NPY-mCherry (Fig. 1a) or Phogrin-mCherry and NPY-PA-GFP-A206K (Fig. 1b) were incubated at $25 \mathrm{mmol} / 1$ glucose and analysed with a resolution of $3.57 \mathrm{~s}$ per frame. Zoomed threedimensional (3D) images using minimal projection revealed downward movement of the activated granule $(0-35.70 \mathrm{~s}$; Fig. 1a). Interestingly, this projection clearly demonstrated
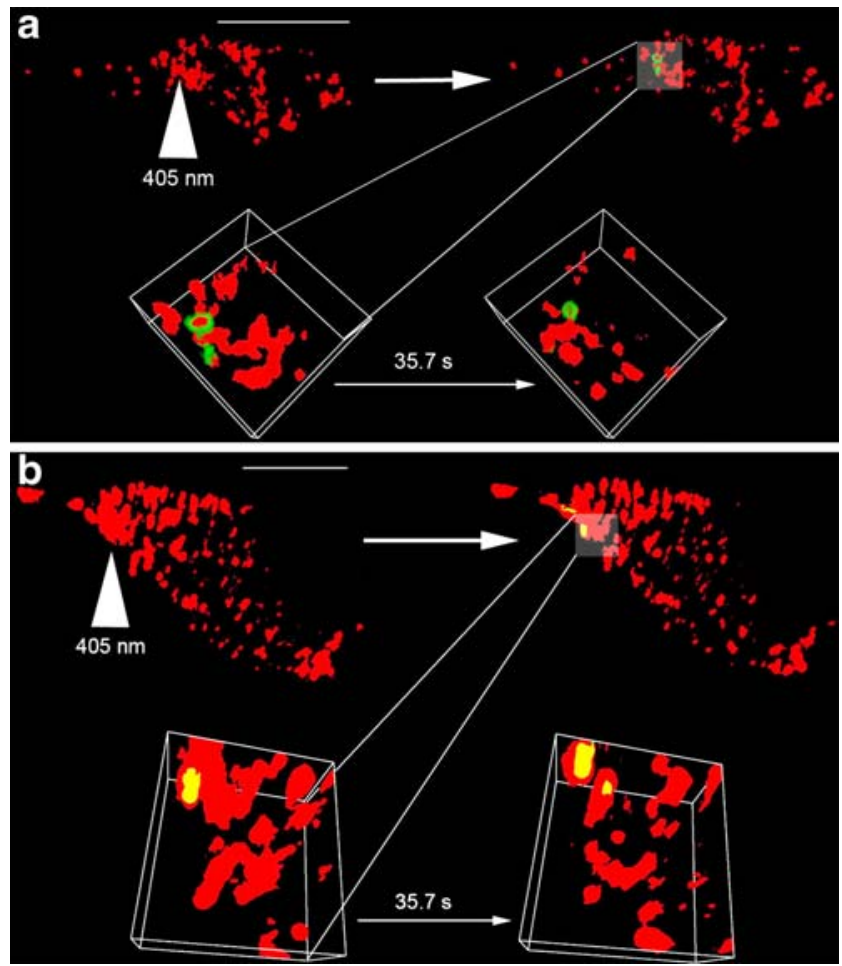

Fig. 1 3D-imaging of insulin secretory granules in MIN6 cells. MIN6 cells were co-transfected with Phogrin-PA-GFP-A206K and NPYmCherry (a) or with Phogrin-mCherry and NPY-PA-GFP-A206K (b) and cultured for $48 \mathrm{~h}$ in DMEM medium with $25 \mathrm{mmol} / \mathrm{l}$ glucose. Thereafter cells were incubated in Krebs-Ringer solution supplemented with $25 \mathrm{mmol} / 1$ glucose and 3D image frames were recorded with a time frame of $3.57 \mathrm{~s}$. Photoactivation of Phogrin-PA-GFPA206K (a) and NPY-PA-GFP-A206K (b) was performed with a $405 \mathrm{~nm}$ laser diode. White arrowhead, region of photoactivation in the MIN6 cell image before photoactivation; horizontal arrows, $35.7 \mathrm{~s}$ process following photoactivation; zoomed $3 \mathrm{D}$ top views, the highlighted region of the whole cell image directly after photoactivation and after $35.7 \mathrm{~s}$ respectively. Images were generated using AutoVisualize X software (MediaCybernetics) and minimal projection (a), where activated PA-GFP-A206K is depicted in green, or maximal projection (b), where activated PA-GFP-A206K appears by colocalisation with red mCherry in yellow. Cells shown are representative of five independent experiments each. Scale bar, $10 \mu \mathrm{m}$ 
the enclosure of the granule cargo visualised by red NPYmCherry via the membrane-localised green Phogrin-PAGFP-A206K. In an experiment with the inverse labelling, zoomed 3D maximal projections allowed analysis of the granule cargo NPY as yellow spots on the background of red-marked Phogrin-mCherry. As initially not visible, two granules on top of each other were activated by the $405 \mathrm{~nm}$ laser path length. Following up the movement $(0-35.70 \mathrm{~s}$; Fig. 1b), the first lower granule appeared then laterally and could be clearly resolved with respect to the second granule.

Characterisation of MIN6-Phogrin-Dendra2 cells MIN6Phogrin-Dendra2 cells stably expressing a Phogrin-Dendra2 fusion construct showed a comparable rate of insulin secretion in response to glucose and $\mathrm{KCl}$ as untransfected MIN6 cells (Fig. 2a,b). The first phase (at 40-45 min of perifusion) secretory response of MIN6-Phogrin-Dendra2 cells to $20 \mathrm{mmol} / \mathrm{l}$ glucose was unaffected by reducing the glucose concentration in the culture medium from 25 to $3 \mathrm{mmol} / \mathrm{l}$ for $48 \mathrm{~h}$ (Fig. 2a). However, in the second phase (at 45-60 min of perifusion) the median insulin release was, at $0.918 \pm 0.045 \mathrm{ng} / \mathrm{min}$ in MIN6-Phogrin-Dendra2 cells precultured at $25 \mathrm{mmol} / 1$ glucose, slightly but significantly $(p=0.0209)$ higher than in MIN6-Phogrin-Dendra2 cells precultured at $3 \mathrm{mmol} / 1$ glucose $(0.736 \pm 0.037 \mathrm{ng} / \mathrm{min})$. Phogrin-Dendra2-labelled granules in MIN6-Phogrin-Dendra2 cells showed distinct colocalisation with insulin after fixation and immunostaining (Fig. 2c,d). Dendra2 is a monomeric dual colour fluorescent protein. Ultraviolet light causes irreversible photoconversion from green Dendra2 to red Dendra2. Overall illumination either with a $405 \mathrm{~nm}$ laser diode by confocal microscopy (data not shown) or with a S360/40 excitation filter by widefield microscopy (Fig. 2e-g) provoked photoconversion of Phogrin-Dendra2.

Quantitative analysis of insulin granule movement after photoconversion of Phogrin-Dendra 2 in MIN6-Phogrin-Dendra 2 cells MIN6-Phogrin-Dendra2 cells were incubated at $25 \mathrm{mmol} / \mathrm{l}$ glucose and analysed with a resolution of $0.729 \mathrm{~s}$ per frame by widefield microscopy over $120 \mathrm{~s}$. Green Phogrin-Dendra2-labelled granules (Fig. 2e) and red PhogrinDendra2-labelled granules (Fig. 2g) after photoconversion using a S360/40 excitation filter were tracked semiautomatically using Imaris software. Average track speed of granules $(n=112)$ from three independent experiments was $0.233 \pm 0.007 \mu \mathrm{m} / \mathrm{s}$ for the green and $0.236 \pm 0.003 \mu \mathrm{m} / \mathrm{s}$ for the red Phogrin-Dendra2-labelled granules. The average track displacement was $2.23 \pm 0.24 \mu \mathrm{m}$. Furthermore MIN6-PhogrinDendra2 cells were analysed with a resolution of $0.428 \mathrm{~s}$ per frame by confocal microscopy over 120 s. Green PhogrinDendra2-labelled granules were tracked semi-automatically using Imaris software. Average track speed of granules $(n=$ 143) from three independent experiments was $0.231 \pm$
$0.007 \mu \mathrm{m} / \mathrm{s}$. The average track displacement was $2.25 \pm$ $0.18 \mu \mathrm{m}$. In comparison only the selectively photoconverted red Phogrin-Dendra2-labelled granules $(n=22)$ from seven independent experiments were tracked automatically using Imaris software, resulting in an average track speed of $0.229 \pm 0.023 \mu \mathrm{m} / \mathrm{s}$ and an average track displacement of $2.30 \pm 0.71 \mu \mathrm{m}$. Also MIN6-Phogrin-Dendra2 cells were analysed with a resolution of $3.57 \mathrm{~s}$ per 3D frame by confocal microscopy over 250 s. Photoconverted red Phogrin-Dendra2-labelled granules $(n=24)$ from seven independent experiments were tracked automatically using Imaris software. The average track speed was $0.094 \pm$ $0.012 \mu \mathrm{m} / \mathrm{s}$ and the average track displacement was $2.18 \pm$ $0.42 \mu \mathrm{m}$. To allow a direct comparison, two-dimensional data of red Phogrin-Dendra2-labelled granules were analysed again, but with a resolution of $2.568 \mathrm{~s}$ per frame, which resulted in an average track speed of $0.107 \pm 0.003 \mu \mathrm{m} / \mathrm{s}$ and an average track displacement of $2.13 \pm 0.13 \mu \mathrm{m}$.

Analysis of insulin granule movement in MIN6-Phogrin-Dendra 2 cells pre-cultured at different glucose concentrations MIN6Phogrin-Dendra 2 cells were incubated for $48 \mathrm{~h}$ in medium with $3 \mathrm{mmol} / \mathrm{l}$ or $25 \mathrm{mmol} / \mathrm{l}$ glucose. Cells were starved for 1 $\mathrm{h}$ and, immediately after addition of Krebs-Ringer solution supplemented with $25 \mathrm{mmol} / 1$ glucose, analysed with a resolution of $3.57 \mathrm{~s}$ per 3D frame by confocal microscopy over 250 s. Selectively photoconverted (Fig. 3a) red PhogrinDendra2-labelled granules $(n=25)$ from seven independent experiments were each tracked automatically using Imaris software. The average track speed in cells pre-cultured at $25 \mathrm{mmol} / 1$ glucose $(0.101 \pm 0.007 \mu \mathrm{m} / \mathrm{s})$ was significantly higher $(p=0.0002)$ than in cells pre-cultured at $3 \mathrm{mmol} /$ 1 glucose $(0.065 \pm 0.007 \mu \mathrm{m} / \mathrm{s}$; Fig. 3b). The average track displacement was also significantly higher $(p=0.0011)$ in cells pre-cultured at $25 \mathrm{mmol} / \mathrm{l}$ glucose $(2.71 \pm 0.26 \mu \mathrm{m})$ than in cells pre-cultured at $3 \mathrm{mmol} / \mathrm{l}$ glucose $(1.54 \pm 0.21 \mu \mathrm{m}$; Fig. 3b). Interestingly, the appearance of red PhogrinDendra2-labelled granules at a time-point after photoconversion was higher in cells pre-cultured at $25 \mathrm{mmol} / \mathrm{l}$ glucose than in cells pre-cultured at $3 \mathrm{mmol} / \mathrm{l}$ glucose (36 vs $20 \%$ respectively; Fig. 3c). Automated analysis, moreover, provided a spatiotemporal characterisation of the movement of single red Phogrin-Dendra2-labelled granules (Fig. 4a,d). Minimal as well as maximal track speed (Fig. 4b) and displacement (Fig. 4c) were lower in cells pre-cultured at $3 \mathrm{mmol} / \mathrm{l}$ glucose than in cells pre-cultured at $25 \mathrm{mmol} /$ 1 glucose (Fig. 4e,f).

\section{Discussion}

Insulin secretory granule mobility in pancreatic beta cells is mediated in a narrow range by random granule diffusion 

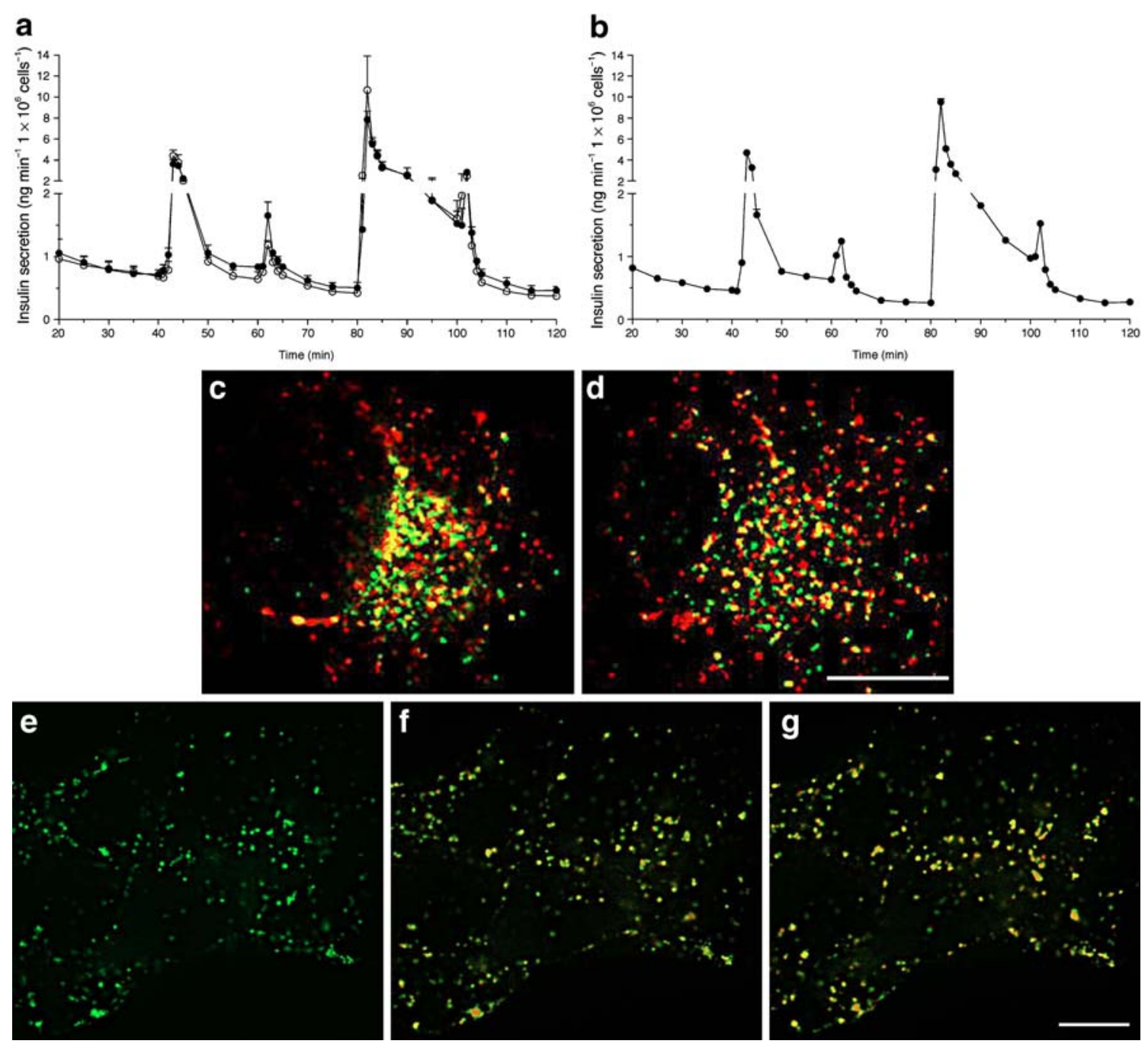

Fig. 2 Insulin secretion and granule visualisation of MIN6-PhogrinDendra2 cells. Perifusion data of (a) MIN6-Phogrin-Dendra2 cells cultured for $48 \mathrm{~h}$ in medium with $3 \mathrm{mmol} / \mathrm{l}$ glucose (white circles) or $25 \mathrm{mmol} / 1$ glucose (black circles) and (b) MIN6 cells cultured for $48 \mathrm{~h}$ in medium with $25 \mathrm{mmol} / \mathrm{l}$ glucose are depicted as a kinetic profile. 20-40 min of perifusion, $0 \mathrm{mmol} / 1$ glucose; $40-60 \mathrm{~min}$ of perifusion, $20 \mathrm{mmol} / 1$ glucose; $60-80 \mathrm{~min}$ of perifusion, $0 \mathrm{mmol} / 1$ glucose; 80 $100 \mathrm{~min}$ of perifusion, $40 \mathrm{mmol} / \mathrm{l} \mathrm{KCl} ; 100-120 \mathrm{~min}$ of perifusion, $0 \mathrm{mmol} / 1$ glucose. Values are means \pm SEM. MIN6-Phogrin-Dendra2 cells were fixed and immunostained for insulin. In the merged images

and over a longer distance by microtubule-driven directed granule translocation [2-11]. Coordination of both is important to replenish the readily releasable secretory granule pool at the plasma membrane $[5,6,8,10,29]$. Visualisation and tracking of granules in living insulinsecreting cells became accessible during recent years thanks to fluorescence-based real-time imaging $[10-13,20,21$, 23]. Photoactivatable fluorescent proteins $[25,30]$ have so far not been used for granule visualisation. In the present study we used PA-GFP-A206K, a protein visible only via green fluorescence after irradiation with ultraviolet light,
Phogrin-Dendra2 is depicted in green and insulin in red. The fluorescence images of (c) a focal cell layer and (d) a cell layer near the plasma membrane were obtained from z-stacks after deconvolution. Living MIN6-Phogrin-Dendra2 cells were imaged (e) before, (f) during and (g) after photoconversion using widefield illumination and a S360/40 excitation filter. In the merged images (e-g) PhogrinDendra2 is depicted in green (before photoconversion) and in red (after photoconversion). Data shown are representative of three independent experiments each. Scale bars, $10 \mu \mathrm{m}$

together with mCherry [24], a monomeric red fluorescent protein with a high photostability, in fusion with phogrin and NPY. After co-transfection, single photoactivated granules can be reliably tracked by their green fluorescence with respect to the stable red marked granules; tracking is possible for a long time and throughout the whole cell including the centre of the cell, where high-resolution TIRF microscopy is not feasible. Using 3D confocal imaging, we were able to resolve the movement of a granule with respect to its red mCherry-labelled cargo and green PA-GFP-A206K-labelled membrane. Prospectively, a combination of photoactivation 
a

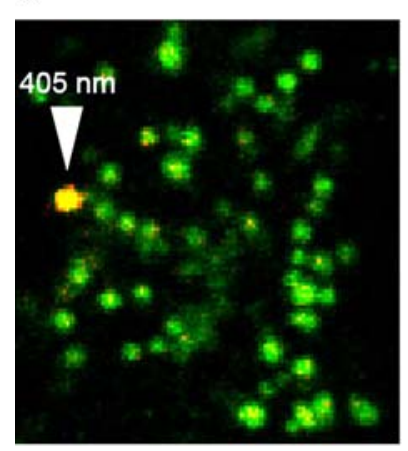

b

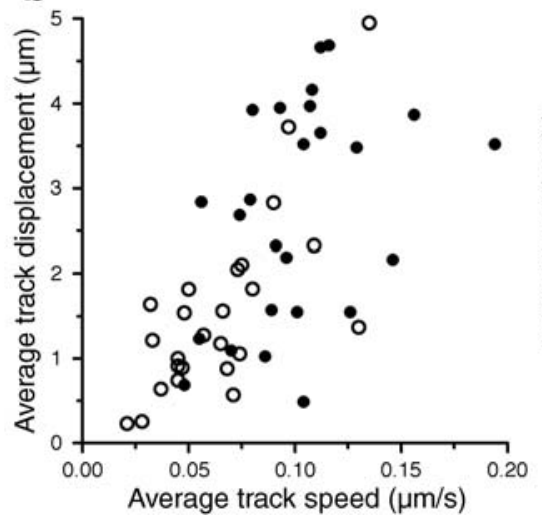

C

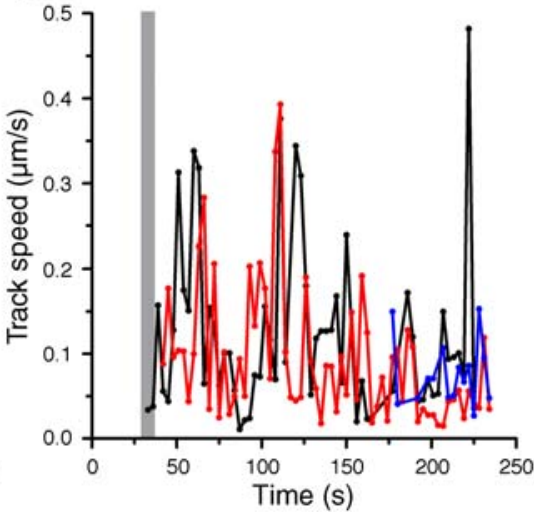

Fig. 3 Effect of low versus high glucose pre-culture on the movement of insulin secretory granules in MIN6-Phogrin-Dendra2 cells. a Region-selected $405 \mathrm{~nm}$ laser light exposure of MIN6-PhogrinDendra2 cells during image acquisition resulted in photoconversion of few Phogrin-Dendra2-labelled granules per cell from green to red (arrowhead). b Cells were starved for $1 \mathrm{~h}$ in Krebs-Ringer solution without glucose. After addition of Krebs-Ringer solution with $25 \mathrm{mmol} / \mathrm{l}$ glucose, 3D image frames were recorded with a sampling interval of $3.57 \mathrm{~s}$. Red Phogrin-Dendra2-labelled granules were automatically tracked using Imaris software. The calculated average track speed was plotted against the average track displacement for cells pre-cultured for $48 \mathrm{~h}$ at $3 \mathrm{mmol} / 1$ glucose (white circles) or $25 \mathrm{mmol} / 1$ glucose (black circles). Data shown are representative of seven independent experiments each. Track speed of three individual granules is shown (c) for a representative cell pre-cultured for $48 \mathrm{~h}$ at $25 \mathrm{mmol} / 1$ glucose. Grey background, photoconversion; black and red line, time resolved track speed of two granules appearing from the outset in the image area; blue line, time resolved track speed of a newcomer granule in the image area and TIRF microscopy may in addition allow a deeper analysis of 'kiss-and-run' mechanisms during exocytosis [3, 23, 31].

We also used Dendra2, a recently developed monomeric photoconvertible protein, as a tool for analysis of granule movement in MIN6 cells [26]. In contrast to PA-GFPA206K, which is colourless before photoactivation, Dendra2 is a fluorescence protein with a green emission spectrum. Upon irradiation with ultraviolet light, Dendra2 undergoes an irreversible conversion to a red fluorescence emission spectrum [26]. We generated a stable MIN6 cell clone expressing a fusion construct of Phogrin and Dendra2. The punctated structure of Phogrin-Dendra2-labelled granules in
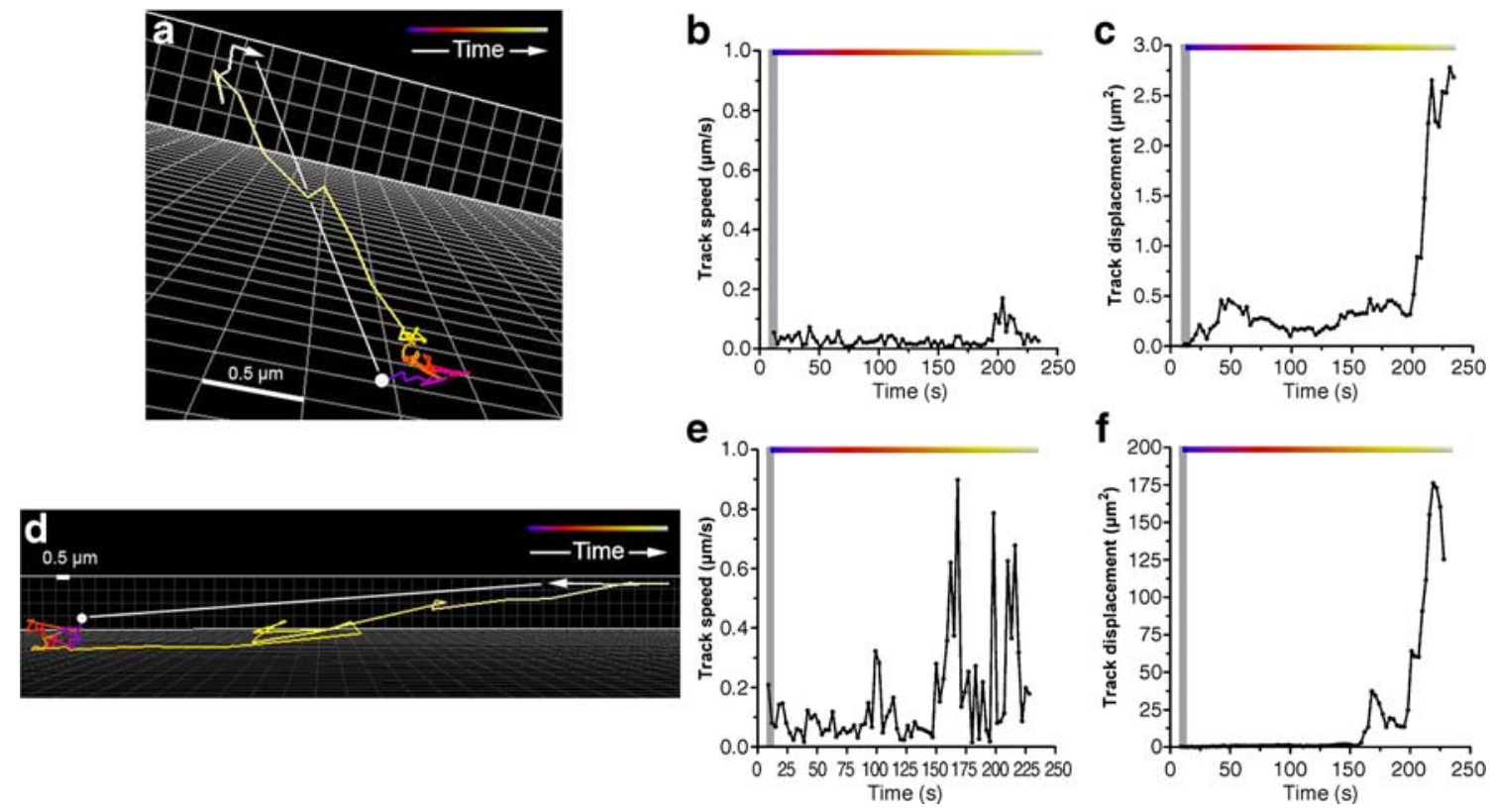

Fig. 4 Analysis of single insulin secretory granule movement in MIN6-Phogrin-Dendra2 cells. Movement of individual red PhogrinDendra2-labelled granules was analysed in MIN6-Phogrin-Dendra2 cells pre-cultured for $48 \mathrm{~h}$ at $3 \mathrm{mmol} / \mathrm{l}$ glucose (a-c) or $25 \mathrm{mmol} / \mathrm{l}$ glucose $(\mathbf{d}-\mathbf{f})$. 3D image frames were recorded with a sampling interval of $3.57 \mathrm{~s}$. The 3D time course of granule movement was generated using Imaris

software (a, d). White circle, initial position of the granule; white arrowhead, last position of granule; white line, average track displacement. The granule track speed $(\mathbf{b}, \mathbf{e})$ and displacement $(\mathbf{c}, \mathbf{f})$ were plotted over time. Grey background, photoconversion; upper coloured line, time course corresponding to the granule path shown $(\mathbf{a}, \mathbf{d})$. The depicted granules are representative of seven independent experiments each 
MIN6-Phogrin-Dendra2 cells corresponds to the staining by an insulin antibody, which is in agreement with previous studies using phogrin-EGFP chimera $[12,16,18]$. Furthermore MIN6-Phogrin-Dendra2 cells showed a comparable insulin secretion to that of MIN6 control cells.

Our results showed that granule movement in MIN6Phogrin-Dendra 2 cells is neither affected by the imaging method nor by the ultraviolet light used for photoswitching. In addition comparable average track speed and track displacement values were obtained by the analysis of the total green Phogrin-Dendra2-labelled granule pool and the selectively photoconverted red Phogrin-Dendra2-labelled granules. However, while analysis of the green Phogrin-Dendra2labelled granules required a manual correction and selection of granules with a track length $>50 \mathrm{~s}$, analysis of photoconverted red Phogrin-Dendra2-labelled granules proceeds fully automatically, because of the lower granule density. Furthermore, immigrating granules could be clearly identified due to the red label. Using 3D imaging, the number of photoconverted red Phogrin-Dendra2-labelled granules that could be analysed for the whole acquisition time of 4 min was increased to $50 \%$. As expected, the calculated track speed decreased with a slower image acquisition time by a constant track displacement value, because of the lower time resolution of granule diffusion. However, our calculated average track speed values $(0.101-0.236 \mu \mathrm{m} / \mathrm{s})$ are in agreement with the average speed range $(0.118-0.286 \mu \mathrm{m} / \mathrm{s})$ reported in another study [12].

While changes in granule movement evoked by temperature [10], $\mathrm{Ca}^{2+}$ concentration $[6,12]$ and stimuli such as $\mathrm{KCl}$ and glucose $[12,32]$ have already been analysed, the effect of a pre-culture at different glucose concentrations on granule movement in insulin-secreting cells has so far not been addressed. We elucidated in MIN6-Phogrin-Dendra2 cells that the average track speed and track displacement of granules after $1 \mathrm{~h}$ starvation and subsequent stimulation with $25 \mathrm{mmol} / \mathrm{l}$ glucose was significantly lower in cells pre-cultured for $48 \mathrm{~h}$ at $3 \mathrm{mmol} / \mathrm{l}$ glucose than in those pre-cultured at $25 \mathrm{mmol} / 1$ glucose. Also the capacity for glucose-induced insulin secretion after the first phase was reduced in cells precultured for $48 \mathrm{~h}$ at $3 \mathrm{mmol} / \mathrm{l}$ glucose. Our results refer to granules of the reserve pool, the purpose of which is to replenish the readily releasable granule pool for the second phase of insulin secretion, and they indicate that glucose has a direct modulating effect on this process. Therefore, our observations support earlier results showing that glucose but not $\mathrm{KCl}$ preserves the readily releasable granule pool by recruitment of new granules [15, 29, 33].

In addition we were able to describe transition from mere diffusion to directed translocation at a higher track speed and displacement of single photoconverted red Phogrin-Dendra2labelled granules in response to glucose with high spatiotemporal resolution. Our results are in agreement with the observation in INS1 cells that granule velocities ranged between 0.1 and $1 \mu \mathrm{m} / \mathrm{s}$ and that frequently the same granule exhibited an apparently random pattern, as well as a much faster mode of translocation [10]. Probably, the transition time-point correlates with a closer vicinity of the marked granule to the microtubules or especially to kinesin [22, 34]. To solve this issue, additional visualisation of the microtubules will be necessary in the future.

Photoactivation- and photoconversion-based real-time imaging of insulin granules, in combination with electrophysiological and functional studies, will open the way to further elucidating the mechanisms of granule movement in pancreatic beta cells. Because of the high spatiotemporal resolution, moreover, this method may also allow the analysis of intracellular granule-granule fusion and granule fission. Such studies could also help to reveal new aspects of defective insulin secretion in patients with type 2 diabetes.

Acknowledgements This work was supported by the European Union (Integrated Project EuroDia LSHM-CT-2006-518153 in the Framework Programme 6 [FP6] of the European-Community). The skilful technical assistance of J. Kresse, B. Lueken and A. Petzold is gratefully acknowledged. The authors thank Olympus Deutschland/Europe (Hamburg, Germany) for technical support. The authors are grateful to J.-I. Miyazaki (Osaka University Graduate School of Medicine, Osaka, Japan) for providing the MIN6 cells, to G. A. Rutter (Imperial College, London, UK) for the Phogrin-EYFP and NPY-Venus vectors, to R. Y. Tsien (Howard Hughes Medical Institute, University of California, San Diego; La Jolla, CA, USA) for the pRSET-B-mCherry vector and to J. Lippincott-Schwartz (National Institute of Child Health and Human Development, National Institutes of Health, Bethesda, MD, USA) for the pPA-GFP-A206K vector.

Duality of interest The authors declare that there is no duality of interest associated with this manuscript.

\section{References}

1. Easom RA (2000) Beta-granule transport and exocytosis. Semin Cell Dev Biol 11:253-266

2. Rorsman P, Renstrom E (2003) Insulin granule dynamics in pancreatic beta cells. Diabetologia 46:1029-1045

3. Ma L, Bindokas VP, Kuznetsov A et al (2004) Direct imaging shows that insulin granule exocytosis occurs by complete vesicle fusion. Proc Natl Acad Sci U S A 101:9266-9271

4. Hutton JC (1989) The insulin secretory granule. Diabetologia $32: 271-281$

5. Henquin JC, Ishiyama N, Nenquin M, Ravier MA, Jonas JC (2002) Signals and pools underlying biphasic insulin secretion. Diabetes 51(Suppl 1):S60-S67

6. Barg S, Eliasson L, Renstrom E, Rorsman P (2002) A subset of 50 secretory granules in close contact with L-type $\mathrm{Ca}^{2+}$ channels accounts for first-phase insulin secretion in mouse beta-cells. Diabetes 51(Suppl 1):S74-S82

7. Varadi A, Ainscow EK, Allan VJ, Rutter GA (2002) Molecular mechanisms involved in secretory vesicle recruitment to the plasma membrane in beta-cells. Biochem Soc Trans 30:328-332

8. Daniel S, Noda M, Straub SG, Sharp GW (1999) Identification of the docked granule pool responsible for the first phase of glucosestimulated insulin secretion. Diabetes 48:1686-1690 
9. Rorsman P, Eliasson L, Renstrom E, Gromada J, Barg S, Gopel S (2000) The cell physiology of biphasic insulin secretion. News Physiol Sci 15:72-77

10. Ivarsson R, Obermuller S, Rutter GA, Galvanovskis J, Renstrom E (2004) Temperature-sensitive random insulin granule diffusion is a prerequisite for recruiting granules for release. Traffic 5:750-762

11. Rutter GA (2004) Visualising insulin secretion. The Minkowski Lecture 2004. Diabetologia 47:1861-1872

12. Hao M, Li X, Rizzo MA, Rocheleau JV, Dawant BM, Piston DW (2005) Regulation of two insulin granule populations within the reserve pool by distinct calcium sources. J Cell Sci 118:5873-5884

13. Michael DJ, Geng X, Cawley NX et al (2004) Fluorescent cargo proteins in pancreatic beta-cells: design determines secretion kinetics at exocytosis. Biophys J 87:L03-L05

14. Ohara-Imaizumi M, Nagamatsu S (2006) Insulin exocytotic mechanism by imaging technique. J Biochem (Tokyo) 140:1-5

15. Ohara-Imaizumi M, Nishiwaki C, Kikuta T, Nagai S, Nakamichi Y, Nagamatsu S (2004) TIRF imaging of docking and fusion of single insulin granule motion in primary rat pancreatic beta-cells: different behaviour of granule motion between normal and GotoKakizaki diabetic rat beta-cells. Biochem J 381:13-18

16. Pouli AE, Emmanouilidou E, Zhao C, Wasmeier C, Hutton JC, Rutter GA (1998) Secretory-granule dynamics visualized in vivo with a phogrin-green fluorescent protein chimaera. Biochem J 333:193-199

17. Rutter GA, Loder MK, Ravier MA (2006) Rapid three-dimensional imaging of individual insulin release events by Nipkow disc confocal microscopy. Biochem Soc Trans 34:675-678

18. Tsuboi T, Zhao C, Terakawa S, Rutter GA (2000) Simultaneous evanescent wave imaging of insulin vesicle membrane and cargo during a single exocytotic event. Curr Biol 10:1307-1310

19. Wasmeier C, Hutton JC (1996) Molecular cloning of phogrin, a protein-tyrosine phosphatase homologue localized to insulin secretory granule membranes. J Biol Chem 271:18161-18170

20. Watkins S, Geng X, Li L, Papworth G, Robbins PD, Drain P (2002) Imaging secretory vesicles by fluorescent protein insertion in propeptide rather than mature secreted peptide. Traffic 3:461-471

21. Ohara-Imaizumi M, Nakamichi Y, Tanaka T, Ishida H, Nagamatsu S (2002) Imaging exocytosis of single insulin secretory granules with evanescent wave microscopy: distinct behavior of granule motion in biphasic insulin release. J Biol Chem 277:3805-3808

22. Varadi A, Ainscow EK, Allan VJ, Rutter GA (2002) Involvement of conventional kinesin in glucose-stimulated secretory granule move- ments and exocytosis in clonal pancreatic beta-cells. J Cell Sci 115:4177-4189

23. Tsuboi T, Rutter GA (2003) Multiple forms of "kiss-and-run" exocytosis revealed by evanescent wave microscopy. Curr Biol 13:563-567

24. Shaner NC, Campbell RE, Steinbach PA, Giepmans BN, Palmer $\mathrm{AE}$, Tsien RY (2004) Improved monomeric red, orange and yellow fluorescent proteins derived from Discosoma sp. red fluorescent protein. Nat Biotechnol 22:1567-1572

25. Patterson GH, Lippincott-Schwartz J (2002) A photoactivatable GFP for selective photolabeling of proteins and cells. Science 297:1873-1877

26. Gurskaya NG, Verkhusha VV, Shcheglov AS et al (2006) Engineering of a monomeric green-to-red photoactivatable fluorescent protein induced by blue light. Nat Biotechnol 24:461-465

27. Baltrusch S, Lenzen S (2007) Novel insights into the regulation of the bound and diffusible glucokinase in MIN6 beta-cells. Diabetes 56:1305-1315

28. Baltrusch S, Francini F, Lenzen S, Tiedge M (2005) Interaction of glucokinase with the liver regulatory protein is conferred by leucine-asparagine motifs of the enzyme. Diabetes 54:2829-2837

29. Olofsson CS, Gopel SO, Barg S et al (2002) Fast insulin secretion reflects exocytosis of docked granules in mouse pancreatic B cells. Pflugers Arch 444:43-51

30. Patterson GH, Lippincott-Schwartz J (2004) Selective photolabeling of proteins using photoactivatable GFP. Methods 32:445450

31. Tsuboi T, Rutter GA (2003) Insulin secretion by 'kiss-and-run' exocytosis in clonal pancreatic islet beta-cells. Biochem Soc Trans $31: 833-836$

32. Ohara-Imaizumi M, Nakamichi Y, Tanaka T, Katsuta H, Ishida H, Nagamatsu S (2002) Monitoring of exocytosis and endocytosis of insulin secretory granules in the pancreatic beta-cell line MIN6 using $\mathrm{pH}$-sensitive green fluorescent protein (pHluorin) and confocal laser microscopy. Biochem J 363:73-80

33. MacDonald PE, Rorsman P (2007) The ins and outs of secretion from pancreatic beta-cells: control of single-vesicle exo- and endocytosis. Physiology (Bethesda) 22:113-121

34. Varadi A, Tsuboi T, Johnson-Cadwell LI, Allan VJ, Rutter GA (2003) Kinesin I and cytoplasmic dynein orchestrate glucosestimulated insulin-containing vesicle movements in clonal MIN6 beta-cells. Biochem Biophys Res Commun 311:272-282 